\section{Effect of Social Support on Quality Of Life, CD4+ T-Cell Count and Viral Load of People Living With HIVIAIDS}

ORIGINAL

\section{Abstract}

Background: Social support is an information leading the subject to believe that is cared, esteemed, and is member of a network of mutual obligations. Studies showed that absence of social support could increase vulnerability to diseases. The purpose of study was to analyze the effect of social support on quality of life (QOL), CD4+ T-cell count and viral load of people living with HIVIAIDS (PLWHA) in ambulatorial service.

Method: This cohort study was a one-year follow-up with first evaluation between August 2012 and August 2013, the second evaluation between August 2013 and August 2014. The sample was 201 subjects, divided in exposed cohort $(\mathrm{N}=134)$, with satisfactory social support, and in not exposed cohort $(\mathrm{N}=67)$, with unsatisfactory social support. Data were collected through interviews using instruments: sociodemographic and clinical form, social support scale, and an instrument for assessing quality of life (WHOQOL-HIV-Bref).

Findings: PLWHA with satisfactory social support no have changes in mean scores of perception of QOL to overall quality of life/general health perception, and in relation to the physical, psychological, social relationships domains, through environment and spirituality/ religion/beliefs. There was difference in level of independence domain $(P=0.022)$, which showed an increase in mean scores related to perceptions of QOL. In the analysis of CD4+ T-cell count and viral load there was no statistically significant difference to PLWHA with unsatisfactory social support.
Gilmara Holanda da Cunha ${ }^{1}$, Marli Teresinha Gimeniz Galvão², Maria Luciana Teles Fiuza ${ }^{3}$, Maria Amanda Correia Lima4, Samyla Citó Pedrosa5, Rosa Maria Salani Mota ${ }^{6}$, Elucir $\mathrm{Gir}^{7}$

$1 \mathrm{PhD}$ in Pharmacology and in Nursing. Adjunct Professor of the Federal University of Ceará (UFC), Department of Nursing, Fortaleza, Ceará, Brazil.

2 PhD in Tropical Diseases. Associate Professor of the Federal University of Ceará (UFC), Department of Nursing, Fortaleza, Ceará, Brazil.

$3 \mathrm{PhD}$ in Nursing. Nurse of the Walter Cantídio University Hospital (WCUH), Fortaleza, Ceará, Brazil.

4 Master's Degree Student in Nursing from the Federal University of Ceará (UFC), Department of Nursing, Fortaleza, Ceará, Brazil.

5 PhD Student in Nursing from the Federal University of Ceará (UFC), Department of Nursing, Fortaleza, Ceará, Brazil.

6 PhD in Public Health, Associate Professor of the Federal University of Ceará (UFC), Department of Statistics and Applied Mathematics, Fortaleza, Ceará, Brazil.

$7 \mathrm{PhD}$ in Nursing, Full Professor of the Nursing School of Ribeirão Preto, University of São Paulo (USP), Ribeirão Preto, São Paulo, Brazil.

Contact information:

\section{Gilmara Holanda da Cunha}

झ gilmaraholandaufc@yahoo.com.br

Keywords

HIV; Quality of life; Social Support. 
Conclusions: PLWHA with satisfactory social support had increased mean scores for the level of independence domain, decreased CD4+ T-cell counts and viral loads.

\section{Introduction}

Highly active antiretroviral therapy (HAART) has reduced morbidity and mortality in patients infected with human immunodeficiency virus (HIV). Since its implementation, monitoring of immunological and virological treatment, as well as genotype-resistance testing for treatment failure management, have been incorporated into patient treatment [1, 2].

In 1996, Brazil adopted a policy of universal access to combination antiretroviral therapy, which was free of charge for people living with HIVIAIDS (PLWHA). As of 2012, approximately 217,000 patients in Brazil were treated with first-, second- or third-line antiretroviral therapy, including newer antiretroviral options for salvage therapy management, leading to an overall reduction in the morbidity and mortality associated with HIV infection [2, 3].

AIDS is a disease that affects not only physical health but also mental and social conditions of patients, because of the negative attitude of society, discrimination, and stigmatization [2]. Previous studies suggested that social support can be an important factor for influencing well-being and quality of life (QOL) [3], mental health [4] and adherence to HAART [5].

Social support appeared prominently in the literature in psychology and related areas beginning in the mid-1970s. Pioneering works of Cassel [6] and Cobb [7] had great relevance to identify the influence of social interactions on well-being and health of people. These studies sought to understand how the absence or the precariousness of social support could increase vulnerability to diseases, as well as whether social support can protect individuals from harm due to physical and mental health due to stress.

Social support is defined as information leading the subject to believe that he is cared for and loved, esteemed, and is a member of a network of mutual obligations. There is evidence that supportive interactions among people are protective against the health consequences of life stress, so that social support can protect people in crisis from a wide variety of pathological states. Furthermore, social support may reduce the amount of medication required, accelerate recovery, and facilitate compliance with prescribed medical regimens [7].

This study aims to determine the effect of social support on QOL, CD4+ T-cell count and viral load of PLWHA. This research has importance for the practice of health promotion, because it identifies aspects of social support of PLWHA; it also provides insight to those who care for these patients, including nurses, the multidisciplinary health care team, family, non-governmental and governmental organizations.

\section{Method}

Prospective cohort study, conducted in infectious diseases clinic of Walter Cantídio University Hospital (UHWC), Fortaleza, Ceará, Brazil. Study was approved by Ethics Committee of UHWC, with registration $\mathrm{N}^{\circ} 040.06 .12$. All patients gave their written, informed consent.

Sample was sized to provide an 95\% confidence for detecting a relative risk of 1.2 for each outcome studied, namely, the ratio between groups exposed and not exposed to social support, in relation to 
the proportion of patients who experienced improved QOL, the CD4+ T-cell count, or the viral load. It was considered that the proportion of expected outcomes among the non-exposed was 0.50 (50\%) and the ratio of unexposed/exposed was 0.5 . Sample size was estimated at 201 individuals, including 67 unexposed to social support (with unsatisfying social support) and 134 exposed to social support (with satisfactory social support).

Inclusion criteria were PLWHA of both sexes, aged over 18 years and use of HAART for at least three months. Exclusion criteria were: mental illness and pregnancy. Withdrawal criteria were: hospitalization, desire to no longer participate of the study and lost to follow up. This study was a one-year follow-up. Data collection for first evaluation occurred between August 2012 and August 2013. Second evaluation occurred between August 2013 and August 2014. Patients were randomly recruited in the ambulatory. Was performed interview in private environment, lasting 40 minutes. Three instruments were used: Sociodemographic and Clinical Form for PLWHA, Social Support Scale for PLWHA, and World Health Organization's Quality of Life Instrument in HIV Infection, abbreviated version (WHOQOL-HIV-Bref).

Social Support Scale for PLWHA was validated in Brazil. Original scale was developed in the Canada [8]. The scale consists of instrumental social support (perception and satisfaction with availability of support in management of operational issues of treatment or health care, practical activities of daily life, material or financial help - ten items) and emotional social support (perception and satisfaction with availability of listening, attention, companionship and emotional support - 12 items). Answers are obtained using five-point Likert scale. For the availability of support: (1) never, (2) rarely, (3) sometimes, (4) often, (5) always. Satisfaction with support received is represented by: (1) very satisfied, (2) dissatisfied, (3) neither satisfied nor dissatisfied, (4) satisfied, (5) very satisfied. To evaluate results, arith- metic mean of items corresponding to each factor is calculated, and the higher the value, greater the perceived availability and satisfaction with the support. For analysis of instrumental social support, scores are summed for the ten items, and result is divided by ten. For emotional social support, scores for the 12 items are summed, and the result is divided by 12 [9].

Allocation of patients into the groups exposed or unexposed to social support was determined by scores obtained after application of Social Support Scale for PLWHA, in the first evaluation of study. People with mean scores equal to 1, 2 and 3 were standardized into the group that had unsatisfying social support, whereas those with scores of 4 and 5 represented people with satisfactory social support. Exposure factor was social support.

WHOQOL-HIV-Bref consists of 31 questions, in six domains: I. Physical (pain, discomfort, energy, fatigue, sleep, rest); II. Psychological (positive feelings, cognition, self-esteem, body image, appearance, negative feelings); III. Level of independence (mobility, activities of daily living, dependence on medication, treatments, fitness for work); IV. Social relationships (personal relationships, social support, sexual activity); V. Environment (physical security, housing, finance, health care, social assistance, ability to acquire information, learn new skills, recreation, physical environment, transport); VI. Spirituality/religion/personal beliefs (forgiveness, guilt, worries about the future, death, dying). It has a facet on the overall QOL and general health perception. Questions are individually scored using Likert scale: 1 (none), 2 (very little), 3 (more or less), 4 (enough) to 5 (extremely), so that 1 indicates negative perceptions and 5 indicates positive perceptions of QOL. Scores ranged between 4-20 points, reflecting the lowest and best perception of $\mathrm{QOL}$, respectively. Scores of domains and facets are arranged in positive direction. In some facets (pain, discomfort, negative feelings, medication dependence, death, dying), scores are not arranged in positive direction, 
meaning that for these scores a higher number does not denote better QOL, and scored need to be reversed [10].

To characterize the level of perception of QOL, the classification of scores was adopted: 4-9.9 represent a lower perception of QOL, 10-14.9, an intermediate perception, and 15-20, a higher perception [11, 12].

Instruments were administered in the first and second evaluation of study, except for the Social Support Scale for PLWHA, administered only in the first evaluation, because it could be a bias of research, since it would increase the patient's perception that he is receiving social support of health professionals.

For analysis of categorical variables, Fisher's exact test on the contingency table was used. MannWhitney test was used to compare two means; Kruskal-Wallis test to compare three or more means, and Wilcoxon test for paired data averages. Where significant differences were observed with application of Kruskal-Wallis test, Hodges-Lehmann test to compare, two by two, the mean was used. Prevalence rate was estimated as statistically significant association, and was identified with application of Fisher's exact test. Quantitative variables were described using mean, standard deviation, median, minimum and maximum values. Value of $\mathrm{P}<0.05$ was considered statistically significant. Software SPSS $\circledR_{\text {, }}$ version 19.0 was used for analysis.

\section{Results}

Were recruited for the study 211 PLWHA. Table 1 shows characterization of these patients. Scores related to instrumental and emotional social support in first evaluation of study showed that most PLWHA had satisfactory social support (Table 2). In the second assessment, scores related to social support were maintained, but the number of patients in each group decreased, with 62 individuals with unsatisfactory social support and 177 with satisfactory social support.

People who provided social support to patients
Table 1. Sociodemographic, clinical and epidemiological characteristics of 211 PLWHA included in the first assessment of the study. Fortaleza, CE, 2014.

\begin{tabular}{|c|c|c|}
\hline Characteristics & $\mathbf{N}$ & $\%$ \\
\hline \multicolumn{3}{|l|}{ Sex } \\
\hline Male & 144 & 68.2 \\
\hline Female & 67 & 31.8 \\
\hline \multicolumn{3}{|l|}{ Self-reported skin color } \\
\hline White & 68 & 32.2 \\
\hline Black & 24 & 11.4 \\
\hline Mixed race & 119 & 56.4 \\
\hline \multicolumn{3}{|l|}{ Schooling (years of study) } \\
\hline$\leq 8$ years & 66 & 31.2 \\
\hline $9-12$ years & 67 & 31.8 \\
\hline$\geq 13$ years & 78 & 37.0 \\
\hline \multicolumn{3}{|l|}{ Marital status } \\
\hline Single & 118 & 55.9 \\
\hline Married & 75 & 35.5 \\
\hline Divorced/widower & 18 & 8.5 \\
\hline \multicolumn{3}{|l|}{ Number of children } \\
\hline No & 104 & 49.3 \\
\hline $1-2$ & 68 & 32.2 \\
\hline$\geq 3$ & 39 & 18.5 \\
\hline \multicolumn{3}{|l|}{ Occupational status } \\
\hline Employed & 131 & 62.1 \\
\hline Unemployed & 55 & 26.1 \\
\hline Retired/temporary leave & 25 & 11.8 \\
\hline \multicolumn{3}{|l|}{ Religion } \\
\hline Catholic & 147 & 69.7 \\
\hline Protestant & 40 & 19.0 \\
\hline Atheist & 24 & 11.3 \\
\hline \multicolumn{3}{|l|}{ Exposure category } \\
\hline Sexual & 175 & 83.0 \\
\hline Unknown & 36 & 17.0 \\
\hline \multicolumn{3}{|l|}{ Sexual orientation } \\
\hline Heterosexual & 134 & 63.5 \\
\hline Homosexual & 57 & 27.0 \\
\hline Bisexual & 20 & 9.5 \\
\hline \multicolumn{3}{|l|}{ Lives with partner } \\
\hline No & 128 & 60.7 \\
\hline Yes & 83 & 39.3 \\
\hline \multicolumn{3}{|l|}{$\begin{array}{l}\text { Anti-HIV serology of the } \\
\text { current partner }\end{array}$} \\
\hline Positive & 44 & 20.9 \\
\hline Negative & 39 & 18.5 \\
\hline Do not know & 7 & 3.3 \\
\hline No partner & 121 & 57.3 \\
\hline
\end{tabular}


Table 2. Analysis of scores after administration of the social support for people living with HIV/AIDS scale in the first assessment of the study. Fortaleza, CE, 2014.

\begin{tabular}{l|c|c|c|c|c|}
\multicolumn{1}{|c|}{ Social support } & N & Mean \pm Standard deviation & Minimum & Median & Maximum \\
\hline Instrumental & & & & & \\
Unsatisfactory & 69 & $2.8 \pm 0.5$ & 1.0 & 2.9 & 3.4 \\
Satisfactory & 142 & $4.0 \pm 0.3$ & 3.5 & 4.0 & 5.0 \\
Total & 211 & $3.6 \pm 0.7$ & 1.0 & 3.8 & 5.0 \\
Emotional & & & & & 5.0 \\
Unsatisfactory & 69 & $3.3 \pm 0.7$ & 1.4 & 3.5 & 5.0 \\
Satisfactory & 142 & $3.9 \pm 0.5$ & 2.0 & 4.0 & 5.0 \\
Total & 211 & $3.7 \pm 0.6$ & 1.4 & 3.9 &
\end{tabular}

were: people of family who did not live in the same household (62.7\%), friends (57.0\%), family members living in same household $(41.5 \%)$, spouse or partner (36.6\%). Those who provided less social support were health professionals (8.5\%), boss and co-workers (6.3\%) and neighbors (5.6\%).

Homosexual and bisexual individuals had more unsatisfactory social support compared with heterosexuals ( $P=0.021)$. Prevalence of unsatisfactory social support among gay men (33.33\%) was higher than among heterosexuals (28.36\%), with a prevalence ratio of 1.175 (95\% Cl: 0.746 to 1.853$)$; however, such data are not significant since the $95 \% \mathrm{Cl}$ contains the unit. For bisexuals, they were twice as likely to have unsatisfactory social support, compared to heterosexuals, since the prevalence ratio was 2.116 (95\% Cl: 1.352 to 3.311) (Table 3).

Mean scores related to physical, psychological, level of independence, environment and spirituality/religion/beliefs domains, showed intermediate perception of QOL. For social relationships domain, the average scores represented a higher perception of QOL. It was further observed that in first assessment, mean QOL scores were lower than in the second assessment for domains level of independence $(P=0.007)$ and spirituality/religion/beliefs $(P=0.048)$, although both represent an intermediate perception of the QOL (Table 4).

For quality of life/general health perception the- re was difference between catholics and atheists $(P=0.007)$, and between protestants and atheists $(P=0.001)$. Atheists had higher average scores than catholics and protestants. For the physical domain, there was difference between catholics and atheists $(P=0.009)$, protestants and atheists $(P<0.001)$, meaning that atheists also had better mean scores in relation to the physical domain. For the level of independence domain, there was difference between protestants and atheists $(P<0.008)$, in that atheists had better mean scores for this domain. Social relationships domain showed difference between catholics and protestants $(P=0.013)$, between protestants and atheists $(P=0.004)$, namely, catholics and atheists had higher average scores than protestants (Table 4).

Living with a partner reduced mean scores of $\mathrm{QOL}$ related to environment domain $(\mathrm{P}=0.042)$. PLWHA employee had higher averages scores than the unemployed $(P=0.016)$. For the level of independence domain $(P=0.046)$, employees also had mean scores higher than those who were unemployed $(P=0.035)$. For the environment domain $(P=0.030)$, mean scores of employees was higher than for who were unemployed ( $P=0.008)$ (Table 4).

Between the first and second evaluation, for PLWHA with unsatisfactory social support, domains of social relationships $(P=0.023)$ and spirituality/religion/beliefs $(P=0.028)$, showed increase in 
Table 3. Association between sociodemographic, clinical and epidemiological characteristics of people with HIV/AIDS and social support in the first assessment of the study. Fortaleza, CE, 2014.

\begin{tabular}{|c|c|c|c|c|c|c|}
\hline \multirow{3}{*}{ Characteristics } & & \multicolumn{4}{|c|}{ Social Support } & \multirow{3}{*}{ P-value* } \\
\hline & & \multicolumn{2}{|c|}{ Unsatisfactory } & \multicolumn{2}{|c|}{ Satisfactory } & \\
\hline & Total & $\mathbf{N}$ & $\%$ & $\mathbf{N}$ & $\%$ & \\
\hline \multicolumn{7}{|l|}{ Sex } \\
\hline Male & 144 & 50 & 34.7 & 94 & 65.3 & 0.431 \\
\hline Female & 67 & 19 & 28.4 & 48 & 71.6 & \\
\hline \multicolumn{7}{|l|}{ Self-reported skin color } \\
\hline White & 68 & 26 & 38.2 & 42 & 61.8 & 0.540 \\
\hline Black & 24 & 9 & 37.5 & 15 & 62.5 & \\
\hline Mixed race & 119 & 34 & 28.5 & 85 & 71.5 & \\
\hline \multicolumn{7}{|l|}{ Schooling (years of estudy) } \\
\hline$\leq 8$ years & 66 & 24 & 36.4 & 42 & 63.6 & 0.728 \\
\hline $9-12$ years & 67 & 20 & 29.9 & 47 & 70.1 & \\
\hline$\geq 13$ years & 78 & 25 & 32.1 & 53 & 67.9 & \\
\hline \multicolumn{7}{|l|}{ Marital status } \\
\hline Single & 118 & 42 & 35.6 & 76 & 64.4 & 0.627 \\
\hline Married & 75 & 22 & 29.3 & 53 & 70.7 & \\
\hline Divorced/widower & 18 & 5 & 27.8 & 13 & 72.2 & \\
\hline \multicolumn{7}{|l|}{ Number of children } \\
\hline No & 104 & 41 & 39.4 & 63 & 60.6 & 0.121 \\
\hline $1-2$ & 68 & 17 & 25.0 & 51 & 75.0 & \\
\hline$\geq 3$ & 39 & 11 & 28.2 & 28 & 71.8 & \\
\hline \multicolumn{7}{|l|}{ Occupational status } \\
\hline Employee & 131 & 38 & 29.0 & 93 & 71.0 & 0.271 \\
\hline Unemployed & 55 & 20 & 36.4 & 35 & 63.6 & \\
\hline Retired/temporary leave & 25 & 11 & 44.0 & 14 & 56.0 & \\
\hline \multicolumn{7}{|l|}{ Religion } \\
\hline Catholic & 147 & 46 & 31.3 & 101 & 68.7 & 0.147 \\
\hline Protestant & 40 & 11 & 27.5 & 29 & 72.5 & \\
\hline Atheist & 24 & 12 & 50.0 & 12 & 50.0 & \\
\hline \multicolumn{7}{|l|}{ Exposure category } \\
\hline Sexual & 173 & 58 & 33.5 & 115 & 66.5 & 0.703 \\
\hline Others $^{\ddagger}$ & 38 & 11 & 28.9 & 27 & 71.1 & \\
\hline \multicolumn{7}{|l|}{ Sexual orientation } \\
\hline Heterosexual & 134 & 38 & 28.4 & 96 & 71.6 & $0.021 \dagger$ \\
\hline Homosexual & 57 & 19 & 33.3 & 38 & 66.7 & \\
\hline Bisexual & 20 & 12 & 60.0 & 8 & 40.0 & \\
\hline \multicolumn{7}{|c|}{ Anti-HIV serology of the current partner } \\
\hline Positive & 44 & 13 & 29.5 & 31 & 70.5 & 0.857 \\
\hline Negative & 39 & 15 & 38.5 & 24 & 61.5 & \\
\hline Do not know & 7 & 2 & 28.6 & 5 & 71.4 & \\
\hline No partner & 121 & 39 & 32.2 & 82 & 67.8 & \\
\hline
\end{tabular}

*Fisher's exact test.

${ }^{\dagger}$ Reason of prevalence in relation to unsatisfactory social support: Heterosexual $(1,000)$, homosexual $(1.175,95 \% \mathrm{Cl} 0.746$ to 1.853), bisexual $(2.116,95 \% \mathrm{Cl} 1.352$ to 3.311$)$

¥Blood transfusion, needlestick accident and unknown. 
Table 4. Association between the scores of the assessment of quality of life of people with hiv/aids scale and the religion, occupational status and the fact of living with a partner, or not, in the first assessment of the study ( $\mathrm{N}=211)$. Fortaleza, CE, 2014.

\begin{tabular}{|c|c|c|c|}
\hline $\begin{array}{l}\text { Domains for assessing Quality of Life of People with HIVIAIDS } \\
\text { Scale (WHOQOL-HIV-Bref) }\end{array}$ & Mean \pm SD* & Median & P-value \\
\hline \multicolumn{4}{|l|}{ GLOBAL QUALITY OF LIFE / GENERAL PERCEPTION OF HEALTH } \\
\hline \multicolumn{4}{|l|}{ Religion } \\
\hline Catholic & $14.1 \pm 1.5$ & 14.3 & \multirow[t]{3}{*}{$0.004+\S$} \\
\hline Protestant & $13.6 \pm 1.8$ & 13.8 & \\
\hline Atheist & $14.9 \pm 1.6 \neq$ & 15.4 & \\
\hline \multicolumn{4}{|l|}{ Occupational status } \\
\hline Employed & $14.3 \pm 1.5 \ddagger$ & 14.6 & \multirow[t]{3}{*}{$0.028+\S$} \\
\hline Unemployed & $13.7 \pm 1.7$ & 13.9 & \\
\hline Retired/away & $13.7 \pm 1.5$ & 13.8 & \\
\hline \multicolumn{4}{|l|}{ I: PHYSICAL } \\
\hline \multicolumn{4}{|l|}{ Religion } \\
\hline Catholic & $14.4 \pm 29$ & 15.0 & \multirow[t]{3}{*}{$0.002+\S$} \\
\hline Protestant & $13.5 \pm 3.2$ & 12.0 & \\
\hline Atheist & $16.2 \pm 3.8 \neq$ & 18.0 & \\
\hline \multicolumn{4}{|l|}{ III: LEVEL OF INDEPENDENCE } \\
\hline \multicolumn{4}{|l|}{ Religion } \\
\hline Catholic & $13.7 \pm 2.6$ & 14.0 & \multirow[t]{3}{*}{$0.029+\S$} \\
\hline Protestant & $12.8 \pm 2.9$ & 13.2 & \\
\hline Atheist & $14.7 \pm 3.1 \neq$ & 15.2 & \\
\hline \multicolumn{4}{|l|}{ Occupational status } \\
\hline Employed & $14.1 \pm 2.6 \neq$ & 14.0 & \multirow[t]{3}{*}{$0.046+\S$} \\
\hline Unemployed & $12.9 \pm 3.1$ & 13.2 & \\
\hline Retired/temporary leave & $13.0 \pm 2.8$ & 15.2 & \\
\hline \multicolumn{4}{|l|}{ IV: SOCIAL RELATIONSHIPS } \\
\hline \multicolumn{4}{|l|}{ Religion } \\
\hline Catholic & $15.4 \pm 2.6$ & 12.0 & \multirow[t]{3}{*}{$0.009+\S$} \\
\hline Protestant & $14.5 \pm 2.7$ & 15.2 & \\
\hline Atheist & $16.2 \pm 2.2 \ddagger$ & 16.4 & \\
\hline \multicolumn{4}{|l|}{ V: ENVIRONMENT } \\
\hline \multicolumn{4}{|l|}{ Lives with partner } \\
\hline Not living with partner & $14.4 \pm 2.2$ & 14.4 & \multirow[t]{2}{*}{$0.042 \ddagger$} \\
\hline Living with partner & $13.8 \pm 2.0$ & 14.0 & \\
\hline \multicolumn{4}{|l|}{ Occupational status } \\
\hline Employee & $14.4 \pm 2.1 \neq$ & 14.4 & \multirow[t]{3}{*}{$0.030+\S$} \\
\hline Unemployed & $13.6 \pm 2.2$ & 13.6 & \\
\hline Retired/temporary leave & $14.3 \pm 1.7$ & 14.4 & \\
\hline
\end{tabular}

*SD: Standard deviation. †Kruskal-Wallis test. ¥Mann-Whitney test.

§Intragroup differences with regard to religion and occupational status were analyzed using the Hodges-Lehmann test. 
mean scores related to perceptions of QOL. Regarding PLWHA with satisfactory social support, there was difference in level of independence domain $(P=0.022)$, which showed an increase in mean scores related to perceptions of QOL. For CD4+ T-cell count and viral load there was difference between the first and second evaluation in regard to PLWHA with unsatisfactory social support. For patients with satisfactory social support there was reduction of CD4+ T-cell count ( $P=0.003)$ and viral load $(P=0.012)$ (Table 5).

Table 5. Association between the scores from the scale for the assessment of quality of life of people with HIVIAIDS (WHOQOL-HIV-Bref), CD4+ T-cell count, viral load and the unsatisfactory or satisfactory social support. Fortaleza, CE, 2014.

\begin{tabular}{|c|c|c|c|c|c|c|}
\hline \multirow{4}{*}{$\begin{array}{l}\text { Domains of the } \\
\text { WHOQOL-HIV-Bref }\end{array}$} & \multicolumn{3}{|c|}{ Unsatisfactory social support } & \multicolumn{3}{|c|}{ Satisfactory social support } \\
\hline & \multicolumn{3}{|c|}{ First Assessment $(\mathrm{N}=69)$} & \multicolumn{3}{|c|}{ First Assessment ( $\mathrm{N}=142)$} \\
\hline & \multicolumn{3}{|c|}{ Second Assessment $(\mathrm{N}=62)$} & \multicolumn{3}{|c|}{ Second Assessment $(\mathrm{N}=115)$} \\
\hline & Mean $\pm S D^{*}$ & Median & P- Value ${ }^{\dagger}$ & Mean \pm SD* & Median & P- Value ${ }^{\dagger}$ \\
\hline \multicolumn{7}{|c|}{ Global quality of life /general perception of health } \\
\hline First assessment & $13.6 \pm 1.9$ & 13.8 & \multirow[t]{2}{*}{0.075} & $14.4 \pm 1.3$ & 14.6 & \multirow[t]{2}{*}{0.359} \\
\hline Second assessment & $14.0 \pm 1.9$ & 14.0 & & $14.5 \pm 1.7$ & 14.5 & \\
\hline \multicolumn{7}{|l|}{ Domain I: Physical } \\
\hline First assessment & $14.7 \pm 3.5$ & 15.0 & \multirow[t]{2}{*}{0.268} & $14.6 \pm 3.0$ & 15.0 & \multirow[t]{2}{*}{0.099} \\
\hline Second assessment & $14.4 \pm 3.1$ & 14.5 & & $15.1 \pm 3.2$ & 15.0 & \\
\hline \multicolumn{7}{|l|}{ Domain II: Psychological } \\
\hline First assessment & $13.2 \pm 2.1$ & 13.6 & \multirow[t]{2}{*}{0.183} & $14.2 \pm 1.7$ & 14.4 & \multirow[t]{2}{*}{0.939} \\
\hline Second assessment & $13.6 \pm 2.0$ & 14.4 & & $14.1 \pm 1.9$ & 14.4 & \\
\hline \multicolumn{7}{|c|}{ Domain III: Level of independence } \\
\hline First assessment & $13.3 \pm 2.9$ & 13.0 & \multirow[t]{2}{*}{0.164} & $13.9 \pm 2.5$ & 14.0 & \multirow[t]{2}{*}{0.022} \\
\hline Second assessment & $13.8 \pm 3.1$ & 14.0 & & $14.6 \pm 2.9$ & 15.0 & \\
\hline \multicolumn{7}{|l|}{ Domain IV: Social relations } \\
\hline First assessment & $14.6 \pm 2.9$ & 14.5 & \multirow[t]{2}{*}{0.023} & $15.9 \pm 2.3$ & 16.0 & \multirow[t]{2}{*}{0.806} \\
\hline Second assessment & $15.3 \pm 2.8$ & 16.0 & & $15.8 \pm 2.7$ & 16.0 & \\
\hline \multicolumn{7}{|l|}{ Domain V: Environment } \\
\hline First assessment & $13.4 \pm 2.2$ & 14.0 & \multirow[t]{2}{*}{0.925} & $14.5 \pm 1.9$ & 14.5 & \multirow[t]{2}{*}{0.267} \\
\hline Second assessment & $13.4 \pm 2.5$ & 13.5 & & $14.3 \pm 2.1$ & 14.5 & \\
\hline \multicolumn{7}{|c|}{ Domain VI: Spirituality/religion/beliefs } \\
\hline First assessment & $13.0 \pm 3.0$ & 14.0 & \multirow[t]{2}{*}{0.028} & $13.3 \pm 2.5$ & 13.0 & \multirow[t]{2}{*}{0.417} \\
\hline Second assessment & $13.9 \pm 3.0$ & 14.5 & & $13.5 \pm 2.5$ & 14.0 & \\
\hline \multicolumn{7}{|l|}{ CD4+ T-cell count (cells/mm³) } \\
\hline First assessment & $562.3 \pm 258.6$ & 546.5 & \multirow[t]{2}{*}{0.935} & $\begin{array}{l}784.7 \pm \\
3.180 .3\end{array}$ & 446.0 & 0.003 \\
\hline Second assessment & $567.9 \pm 246.3$ & 584.0 & & $532.9 \pm 207.7$ & 501.0 & \\
\hline Viral load (copies/ml) & & & & & & \\
\hline First assessment & $\begin{array}{c}4,648.8 \\
\pm 16,752.6\end{array}$ & 0.0 & 0.405 & $\begin{array}{c}3,824.6 \pm \\
15,928.1\end{array}$ & 0.0 & 0.012 \\
\hline Second assessment & $\begin{array}{c}4,005.6 \\
\pm 26,657.0\end{array}$ & 0.0 & & $\begin{array}{c}1,011.2 \pm \\
5,973.2\end{array}$ & 0.0 & \\
\hline
\end{tabular}

*SD: Standard deviation.

${ }^{\dagger} \mathrm{P}$ : Wilcoxon test. 


\section{Discussion}

Male patients were predominant in the sample, which is consistent with other studies [5, 13]. Most patients self-reported as being of mixed race, followed by whites. Research conducted in the United States also pointed out that the number of caucasians with HIVIAIDS is much lower compared with the African-Americans, however, there is increasing trend in the number of HIV-infected individuals among whites compared with African-Americans [14].

Analysis of education of PLWHA showed that the majority had higher education, in disagreement with other studies in which lower education prevails, and which indicates the progressive spread of the epidemic on social strata with lower educational degrees [13]. Many patients were single. According to research, unmarried are more likely to have multiple partners, increasing their vulnerability to HIV [15]. Most PLWHA were employed, this is due to HAART, which slows the progression of infection. The normalization of employment can help PLWHA to replace the identity of the patient, because those who worked reported an improvement in QOL [4]. But high unemployment rates are common among PLWHA, because of the stigma $[2,4]$.

The most of the PLWHA claimed to be catholic. It is noteworthy that some patients begin to assign to religion the treatment and cure of HIVIAIDS, not properly adhering to HAART and other health guidance [16]. Regarding the exposure category, the most obvious was sexual, with the majority of patients reporting being heterosexual, in opposition to the early days of the epidemic, when most were homosexuals, drug users and blood transfusion recipients [17].

Values of social support scores identified in this study were similar to the Brazilian validation study of the Scale of Social Support for PLWHA(9), as well as the data from the original Canadian study [8]. Prevalence of unsatisfactory social support was higher among homosexuals and bisexuals, compa- red to heterosexuals. The prejudice causes PLWHA have less contact with other people because of the stigma, contributing negatively to the maintenance of satisfactory social support [18].

Mean QOL scores were similar to other studies conducted in Brazil that used the same scale, highlighting the intermediate perception of $\mathrm{QOL}$ for most domains [11, 12]. In relation to international research, there were some differences. In a study in Portugal that validated and applied the WHOQOL-HIV-Bref, PLWHA had a lower score on QOL than the Brazilians [19]. In another study in Bangladesh, the average scores showed a lower perception of QOL [20]. Living with a partner was related to lower average scores in relation to the environment domain, although the perception of PLWHA on QOL remained at the intermediate level. Presence of many members in the family is a risk factor for non-adherence to HAART and reduction in financial resources, because there is a lack of time to attend follow-up consultations in health and problems occur due to the competing needs of the routine of other family members [21]

Among PLWHA who participated in the study, the atheists had mean scores of QOL that were higher than catholics and protestants. It is observed that most of the PLWHA who practice a religion are those with lower QOL parameters, have the worst health, and more problems with adherence to HAART. Research has shown that patients who believed more in God and regularly participated in religious rituals were less likely to adhere to HAART, influencing negatively their general health, as well as QOL [22].

It was noted that PLWHA who were employed at the time of study had higher mean QOL scores than those who were unemployed, in domains of overall quality of life/general health perception, level of independence and environment. Regarding the fact that PLWHA work, discriminatory practices can occur at time of hire, during course of employment and at dismissal, which can offend the dignity of 
worker and principle of equality [23].

Unsatisfactory social support improved the mean scores of QOL in the social relationships domain. Something that may explain this finding is that PLWHA, despite having unsatisfactory social support, may start to seek new forms of social support, or value the little support they receive. Unsatisfactory social support due to the stigma of illness can cause mental suffering of PLWHA, and the individual may feel the need for and seek new forms of support. Family members are more involved in providing social support to PLWHA [2].

Regarding the domain of spirituality/religion/beliefs, there was also an increase in average QOL scores. One hypothesis that explains this is that when people are more dissatisfied with the social support they receive, they seek a religion to feel spiritually supported. This process is called coping strategy [16]. PLWHA who had satisfactory social support had increased mean QOL scores in relation to the level of independence domain. Satisfaction with social support and coping ends up being a positive predictor of adherence to HAART [5]. Higher the level of dependence, the more impossible to develop self-care [17].

Unsatisfactory social support did not affect the CD4+ T-cell count and viral load. For patients who had satisfactory social support, a reduction of viral load and CD4+ T-cell count was found. These results agree with another study, in which PLWHA who received more social support had a lower viral load [24]. This seems to occur because satisfactory social support is associated with better adherence to HAART [5].

PLWHA who have satisfactory social support have reduced CD4+ T-cell count. This can be explained because the course of HIV infection follows a pattern. In the initial phase of infection there is exponential increase in viral load, followed by appearance of cellular immune response. The second stage is known as chronic infection, in which the diversity of virus in the host increases and CD4+ T-cell count decreases. In the third, there is decrease the CD4+ T-cell count and increase in viral load occurs, causing opportunistic diseases [25]. This study, social support cannot be considered to be influence on CD4+ T-cell count, because these cells may be reduced by time of disease progression. This finding also contradicts results of research in which satisfactory social support was related to increased CD4+ T-cell count.

\section{Conclusion}

There was a reduction in the CD4+ T-cell count and viral load, and improvement in the mean scores of perception of QOL for the level of independence domain of the WHOQOL-HIV-Bref. Limitations of the study involve the lack of analysis of patients' adherence to HAART, because this information could explain the results related to the CD4+ T-cell count and viral load, and the study be only conducted for one year. Longer follow-up period, changes could occur in terms of satisfactory and unsatisfactory social support, and the patients would change in terms of their exposure group, representing a confounding variable for statistical analysis.

It is suggested new studies that address the limitations of this research, because practices of health promotion involving social support can improve the adherence to HAART, mental health and interpersonal relationships, reducing the morbidity and mortality of PLWHA, while for HIVIAIDS there is still no cure.

\section{References}

1. Reis RK, Haas VJ, Santos CB, Teles AS, Galvão MTG, Gir E. Symptoms of depression and quality of life of people living with HIVIAIDS. Rev. Latino-Am. Enfermagem. 2011;19(4):874-81.

2. Rueda S, Raboud J, Mustard C, Bayoumi A, Lavis JN, Rourke SB. Employment status is associated with both physical and mental health quality of life in people living with HIV. AIDS Care, 2011;23(4):435-43.

3. Persson L, Ostergren PO, Hanson BS, Lindgren A, Naucler A. Social network, social support and the rate of decline of CD4 lymphocytes in asymptomatic HIV-positive homosexual men. Scand J Public Health. 2002;30(3):184-90. 
4. Liu L, Pang R, Sun W, Wu M, Qu P, Lu C, et al. Functional social support, psychological capital, and depressive and anxiety symptoms among people living with HIVIAIDS employed fulltime. BMC Psychiatry. 2013;1(13):324.

5. Gardenier D, Andrews CM, Thomas DC, Bookhardt-Murray LJ, Fitzpatrick JJ. Social support and adherence: differences among clients in an AIDS day health care program. J Assoc Nurses AIDS Care. 2010;21(1):75-85.

6. Cassel J. The contribution of the social environment to host resistance: the fourth wade hampton frost lecture. Am J Epidemiol. 1976;104(2):107-23.

7. Cobb S. Social support as a moderator of life stress. Psychosom Med. 1976;38(5):300-14.

8. Renwick R, Halpen T, Rudman D, Friedland J. Description and validation of a measure of received support specific to HIV. Psychol Rep. 1999;84(2):663-73.

9. Seidl EMF, Zannon CMLC, Tróccoli BT. Persons living with HIV/ AIDS: coping, social support and quality of life. Psicol. Reflex Crit. 2005;18(2):188-95.

10. Zimpel RR, Fleck MP. Quality of life in HIV-positive brazilians: application and validation of the WHOQOL-HIV, Brazilian version. AIDS Care, 2007;19(7):923-30.

11. Santos ECM, França Júnior I, Lopes F. Quality of life of people living with HIV/aids in São Paulo, Brazil. Rev Saúde Pública. 2007;41(2):64-71

12. Costa TL, Oliveira DM. Quality of life of people with human immunodeficiency virus and interiorizarion: multidimensional assessment. J Nurs UFPE on line. 2013;7(10):5866-75.

13. Tang H, Mao Y, Shi CX, Han J, Wang L, Xu J, et al. Baseline CD4 cell counts of newly diagnosed HIV cases in China: 2006-2012. PLoS One. 2014;9(6):e96098.

14. Lee S, Ko J, Tan X, Patel I, Balkrishnan R, Chang J. Markov chain modelling analysis of HIVIAIDS progression: a race-based forecast in the United States. Indian J Pharm Sci. 2014;76(2):10715.

15. Gant Z, Lomotey M, Hall HI, Hu X, Guo X, Song R. A countylevel examination of the relationship between hiv and socia determinants of health: 40 States, 2006-2008. Open AIDS 2012;6:1-7

16. Hampton MC, Halkitis PN, Mattis JS. Coping, drug use, and religiosity/spirituality in relation to HIV serostatus among gay and bisexual men. AIDS Educ Prev. 2010;22(5):417-29.

17. Cunha GH, Galvão MTG. Nursing diagnosis in patients with human immunodeficiency vírus/acquired immunodeficiency syndrome in outpatient care. Acta paul. enferm. 2010;23(4): 526-32.

18. Earnshaw VA, Jin H, Wickersham J, Kamarulzaman A, John J, Altice FL. Exploring intentions to discriminate against patients living with HIVIAIDS among future healthcare providers in Malaysia. Trop Med Int Health. 2014;19(6):672-9.

19. Canavarro MC, Pereira M. Factor structure and psychometric properties of the European Portuguese version of a questionnaire to assess quality of life in HIV-infected adults: the WHOQOLHIV-Bref. AIDS Care. 2012;24(6):799-807.

20. Imam MH, Karim MR, Ferdous C, Akhter S. Health related quality of life among the people living with HIV. Bangladesh Med Res Counc Bull. 2011;37(1):1-6.

21. Harris J, Pillinger M, Fromstein D, Gomez B, Garris I, Kanetsky PA, et al. Risk factors for medication non-adherence in an HIV infected population in the Dominican Republic. AIDS Behav. 2011;15(17):1410-5.

22. Vyas KJ, Limneos J, Qin H, Mathews WC. Assessing baseline religious practices and beliefs to predict adherence to highly active antiretroviral therapy among HIV-infected persons. AIDS Care. 2014;26(8):983-7.

23. Gunther LE, Baracat EM. HIV and AIDS: prejudice, discrimination and stigma at work. Revista Jurídica. 2013;1(30):398-28.

24. Burgoyne RW. Exploring direction of causation between social support and clinical outcome for HIV-positive adults in the context of highly active antiretroviral therapy. AIDS Care. 2005;17(1), 111-24

25. Alizon S, Magnus C. Modeling the course of an HIV infection: insights from ecology and evolution. Viruses. 2012;4(10):19842013.

\section{Publish in International Archives of Medicine}

International Archives of Medicine is an open access journal publishing articles encompassing all aspects of medical science and clinical practice. IAM is considered a megajournal with independent sections on all areas of medicine. IAM is a really international journal with authors and board members from all around the world. The journal is widely indexed and classified Q2 in category Medicine. 